\title{
Who Owns the Central Mosque? Ethnic Identity and the Struggle for Spiritual Space in Epe, Southwest Nigeria
}

\author{
Moruff Mudasiru \\ University of Ibadan \\ muffyakande@yahoo.com
}

\begin{abstract}
Religion and ethnicity are core attributes of identity in West Africa, and the majority of the population defines itself in relation to these values. But most studies of religious conflict in Nigeria focus on the conflicts between the two great world religions, Islam and Christianity. Equally, studies of ethnic conflict tend to focus on conflict between different language groups. This article shows that it is also important to focus on sub-ethnic difference, and the meso-level conflicts and tensions that often occur within each faith. In Epe, a coastal town in Lagos, southwest Nigeria over eighty percent of the population profess Islam, but remain distinguished as different social and ethnic sub-groups, as "ljebu Epe" and "Eko Epe." Over time, both groups invested in ethno-religious contestation, which led to open conflict when they were brought together in the same local Council and differed over the ownership of the only Central Mosque in the town. The study shows that the struggle for the soul of the first Epe Central Mosque at Oke Balogun between ljebu Epe and Eko Epe was used in pursuit of both spiritual and political power, and in order to gain control over important resources. This study therefore provides empirical evidence that ethnic and group differences do affect some aspects of religious practices and can even lead to rivalry within the same religion.
\end{abstract}




\section{Introduction}

Religion and ethnicity are core aspects of identity formation across West Africa. Especially religion provides a moral order and support for individuals and groups, which is in turn reflective of the morality desired in society. ${ }^{1} \mathrm{Un}$ cooperative relations and violence between adherents of religious faiths emanate mainly from differences in doctrines, patterns of worship and conflicting interpretations of the holy books.

However, religious conflict occurs more frequently when these differences are also identified with different social groups or classes. Similarly, ethnicity, as Thomas Hylland Eriksen posits, "emerges and is made relevant through social situations and encounters and through people's ways of coping with the demands and challenges of life." 2 Again, ethnicity offers a fruitful context for understanding violence as most ethnic conflicts or tensions arise from interactions between agents who consider themselves as culturally distinctive from members of other groups. Thus, ethnic and religious issues are obviously among the most frequently recurring issues in Nigeria's body politic and beyond. The issue has permeated the landscape since the colonial period and up till the present time, and there seems to be no solution in sight to the accompanying conflicts of ethnic rivalry and religious intolerance. The dominant and minority ethnic groups treat each other with suspicion and different religious worldviews clash at the slightest provocation. ${ }^{3}$

Contemporary studies of ethno-religious conflicts in Africa have been particularly interested in protracted social conflicts. Such conflicts can be defined as hostile and violent interactions between identity groups over a long time, based on deep-seated ethnic, racial and religious hatred, structural cleavages between the conflicting groups, and the political oppression of some groups along with the denial of their fundamental needs. ${ }^{4}$ No doubt, the focus on group identities has come to shape the discourse of faith in Africa as a competition between the two big monotheistic world religions - Islam and Christianity. Most academic discourse that focuses on religious conflict in Nigeria is

1. Irene N Osemeka, "The Management of religious Diversity in West Africa: the excepcionalism of the Wolof and Yoruba in the post-independence period", Historia Actual Online 33 (2014): 61-75.

2. Thomas Hylland Eriksen, Ethnicity and Nationalism: Anthropological Perspective (2 $2^{\text {nd }}$ ed; London: Pluto Press, 2002).

3. Olu-Adeyemi, 2006. "Ethno-Religious Conflicts and the Travails of National Integration in Nigeria's Fourth Republic," https://www.dawodu.com/adeyemi3.htm, accessed February $13,2017$.

4. R.J. Fisher, "The Potential for Peace-building: Forging a Bridge from Peace-keeping to Peacemaking," Peace and Change, 18.5 (1993): 247-66. 
characterized by similar bifurcated understanding. ${ }^{5}$ But in addition to the conflicts between the two great world religions are also meso-level conflicts and tensions that often occur within each faith. It is therefore imperative to not only concentrate on the inter-faith conflicts but also to examine critically the intra-faith dynamics of religious tensions and conflicts in our society.

This study of ethnic identity and the struggle for the control of the Central Mosque, a spiritual space in Epe town, Lagos State, Nigeria falls within the exploration of intra-faith conflicts as it focuses on the disagreements between different groups within the overall Muslim-dominated settlement of Epe. Epe is a coastal settlement of two Yoruba communities, which identify either with Lagos (Eko) or Ijebu.

In particular, this article focuses on how the struggle and competition for the control of spiritual space between 'Ijebu Epe' and 'Eko Epe' within the same Central Mosque of a Muslim Community is imagined as a social instrument of subjugation and persecution, in spite of the fact that Islam provides the institutions, the framework and the guidelines for realizing the cohesion and strength of Muslims. In other words, the article identifies sub-ethnic identity as the mobilizing factor in the struggle for the control of Epe Central Mosque. It explores the historic narratives of conflict and tension over the control of the central mosque, which resulted in the eventual closure of the only Central Mosque in Epe community by the then British Government in 1931, and which continues to be the cause of incessant tension and misunderstandings in the town.

Through an ethnographic study in the Muslim-dominated town of Epe, the study observes the consequence of ethnic cleavage between the Ijebu Epe and 'Eko Epe' within the same Ummah in an urban setting. Often the rejection of internal diversity within Islam and the attempt to consolidate a "true" and "pure" line, ritual or theology is understood as a form of religious fundamentalism. ${ }^{6}$ But as I show in this article, the refusal to tolerate differences within the Epe Muslim community is not only sectarian but it is also ethnically motivated.

This study also emphasizes that the combination of ethnic and religious difference is not limited to groups of different ethnic backgrounds or of different religions. Like in the conflict between Ife and Modakeke, the conflict between the Ijebu Epe and the Lagos Epe is one between Yoruba sub-groups. While the Yoruba unite to compete with other groups for federal resources, Yoruba subgroups such as Ijesa, Ekiti, Egba, Ijebu, Ibadan also compete within

5. Hashim Yahaya and J. Walker, "Marginal Muslims: Ethnic identity and the Ulama in Kano," in Abdul Raufu Mustapha, ed., Sects and Social Disorder: Muslim Identities and Conflict in Northern Nigeria (NY: Western Africa Series, 2014).

6. Ibid. 
the Yoruba zone for space and dominations. ${ }^{7}$ However, while the Ife and Modakeke are also identified with different religions, this is not the case among Epe's Muslims. The contribution of this study will therefore be to challenge the usual dichotomous understanding of Muslim-Christian difference as the exclusive cause of religious conflict in Nigeria.

Epe is one of the ancient and major towns in Lagos State, Nigeria. It is located on the northern shore of the Lagos lagoon, about 32 kilometers south of Ijebu-Ode and about 77 kilometers away from Lagos Island. The inhabitants are distinguished along the ethnic categories of Ijebu Epe and Eko Epe, but as it is generally believed that over eighty percent of the population profess the Islamic faith, Islam constitutes an integral part of the social sphere of Epe town.

\section{The beginnings of Islam in Epe}

The town of Epe was founded as a settlement of the Ijebu people and it served as the chief port transporting slaves, cloth and agricultural produce from Ijebu-Ode to Lagos or eastwards along the lagoon and coast. Consequently, the Ijebu of Epe people worshipped many of the deities prominent in the Ijebu kingdom. The local pantheon of deities was expanded by Ijo and Ilaje who came in from the eastern side of the lagoon, the creeks of the Niger delta and the coast more generally as fishermen or traders.

Their contribution to Epe included some minor deities but also the social institution of Aiyelala, an important deity from the Ikale and Ilaje areas that is believed to have the special power of detecting and punishing evil doers, witches and wizards and rendering them virtually powerless. ${ }^{8}$

Islam was introduced and strengthened during the presence of Oba Kosoko of Lagos. After his expulsion from Lagos in 1851, Kosoko founded an important new settlement at Epe, which included many Muslims and was soon a center of Islamic practice. ${ }^{9}$ When Kosoko returned to Lagos in 1862 as the Oloja Ereko, many of his followers remained in Epe and continued to practice and spread Islam. Over time, original reservations over Islam were overcome and the Muslim faithful came together openly for prayer and worship. When Islam flourished, many people adopted it as a way of life in the Epe community. ${ }^{10}$

7. Toyin Falola, Yoruba Gurus: Indigenous production of knowledge in Africa (Trenton: Africa World Press, 2008), 185.

8. M.A. Balogun, "Syncretic Beliefs and Practices amongst Muslims in Lagos State Nigeria: with special reference to the Yoruba speaking people of Epe," (Unpublished doctoral dissertation, University of Birmingham, 2011), 98.

9. J.S. Eades, Yoruba Today (London: Cambridge University Press, 1980).

10. T.G.O. Gbadamosi, The Growth of Islam among the Yoruba, 1841-1908 (London: Longman, 1978). 
Among the heads of groups that had followed King Kosoko and converted to Islam, it became fashionable to build a mosque in their compounds because this helped them to attract their people in their respectively immediate environments to Islam. Several Mosques were built in each ward and quarters in the town. Indeed, the Muslim leaders did not only confine their attention to Epe town alone but many Alfas went from village to village nearby to spread Islam and Mosques were built in the outlying villages close to Epe too. The spread of Islam was aided by the Epe chiefs such as Balogun Agbaje, Balogun Iyanda, and Balogun Ajeniya who was seen as the greatest pioneer and promoter of Islam.

To unite the community, the first Central Mosque of Epe was built in 1862 . It was built close to Balogun Ajeniya's compound, which is the location where the town's first mosque, also known as Sunmonu mosque, had been built. Mohammad Audu, a newcomer who was versed in the Quran, had spent his life teaching old and new adherents the doctrines of the religion.

As the Muslim community grew in strength, the choice for the Chief Imam fell on Audu. Generally, the growth of Islam in this period was linked to the movements of clerics and traders who were often the cultural agents of Islam. As numbers of converts increased, many local scholars and preachers emerged, and many people adopted Islamic codes of conduct. ${ }^{11} \mathrm{~A}$ growing number of socio-legal matters were decided in accord with the Islamic Maliki legal tradition in the presence of the traditional chiefs by the Chief Imam.

The high percentage of Muslims and its tradition of Islamic law make Epe one of the most explicitly Muslim Yoruba towns apart from Ilorin, and similar to Ede, Ikirun and Iwo. The Islamic nature of Epe is reflected by the high regard which Yoruba Muslims have for Epe as a Muslim citadel in Yorubaland, expressed in the proverb,

\section{Epe l'oni Kurani \\ Epe is the owner of Quran}

The wide appreciation of Islam is also expressed within Epe itself, where people often remind each other that,

Esin Islam la ntele ni bi.

We follow Islam here.

The growth of the community was associated with the elaboration of organizational structure and the construction of modern and bigger Mosques in various villages and quarters across the Epe community. At the time of Balo-

11. S. Oyeweso, Journey from Epe: Biography of S.L. Edu (Lagos: West African Book Publishers Limited, 1996), 9. 
gun Ajeniya's death in 1875, the Muslims among the Eko-Epe were well organized politically. They had a Muslim ruler or Baale and a hierarchy of leaders that was entirely composed of faithful Muslims. One of the reasons that Islam was so successful was that its association with learning, clear organizational structures and the building of mosques was widely perceived as a reflection of general progress, in which the Epe Muslim community led the rest of the Yoruba society.

\section{Growth and the emerging tensions in the Muslim community}

But the success of Islam also resulted in important changes and tensions within the community itself. King Kosoko's presence in Epe had been condoned by the Awujale Anikilaya, the paramount ruler of Ijebu, and was therefore accepted by the Epe Ijebu. Certainly, many citizens of Epe were highly delighted with Kosoko's expansion of control over the lagoon trade, which also extended Epe's influence along the lagoon, making it one of the most important trading centers of the time.

However, after Kosoko's return to Lagos, many of the town's original inhabitants felt that those of his followers who stayed behind should now adapt to the existing town structures and recognize the existing structures of power. This sat uneasily with Kosoko's followers, now considered Eko Epe (Lagos Epe), who was very aware of their own contribution to the town. Eko Epe Chief Akinpelu Iposu assumed the headship of the community shortly after Kosoko had left. While he was not successful in holding on to Palma and Lekki, which had been part of Epe under Kosoko, the fact that he was recognized by Lagos in 1863 strengthened his position in the town. Even so, his attempt to unite the Ijebu and Eko Epe under his leadership failed, and he had to leave for Lagos in $1865 .^{12}$

After Chief Iposu, Chief Iyanda Oloko took over the leadership of the Eko Epe. He took the title of Baale and set up an advisory council that was also constituted solely of Muslims. At this point the separation between the Eko Epe and the Muslim community became difficult, because the Baale settled both disputes among Muslims and disputes among the Eko Epe. As the Eko Epe became an almost exclusively Islamic community, their view of the Ijebu Epe also changed, and they increasingly saw them as outsiders to their Eko Epe community on the basis of their religion. Even when Ijebu Epe converted to

12. Philip Oloruntola, "The Balogun Institution in Epe," in Oluwasegun Mufutau Jimoh and Philip Oloruntola, eds, The Balogun in Yorubaland The Changing Fortunes of a Military Institution (Ibadan: Bookbuilders, 2016), 120-1. 
Islam, they were somehow considered by the Ijebu Epe as non-Muslims or non-orthodox Muslims. ${ }^{13}$

As the Eko Epe increasingly saw themselves as the group that practiced pure Islam, they saw most of their scholars as those who wanted to reform and purify the practices of Islam, and the scholars of the Ijebu Epe as those who desired to stick to older practices that were, from the point of view of strict Islamic orthodoxy, erroneous. ${ }^{14}$ While disputes between reformers and social conservatives took place in many Yoruba Muslim communities as Islamic learning increased, the differences between the Islamic purists and the social conservatives in Epe clearly reflected the differences between the Ijebu Epe and the Lagos group.

The perception of the Ijebu Epe was not entirely without foundation: some Ijebu Epe Muslims continued to participate regularly in the traditional institutions like the Osugbo, Iji Nla, and the various masquerades and festivals that they believed could contribute to the wellbeing and safety of the town. Many Ijebu Epe Muslims participated at least occasionally in rituals and the worship of deities to nurture their link with the ancestors and attain fertility, healing and the reverse of different predicaments.

They justified these practiced by saying,

Igbagbo ko ni ka wa ma soro ile wa.

Religion does not mean that we should abandon the rituals of our house.

However, it is difficult to say to what degree such practices were also encouraged by the perceived domination of the Eko Epe. It is certainly the case that the by then defunct title of the Oloja, the traditional ruler of (Ijebu) Epe, was revived as a counterweight to Baale Oloko: Oloja Sagbafara was installed in 1866, and it was under him that many of the traditional institutions of the town were revived or re-consolidated. In this way, the Ijebu Epe used their ancestral link to Epe to assert themselves against the Eko Epe. ${ }^{15}$

In contrast, most Eko Epe, who had severed their ties with their home communities in various ways by following King Kosoko, was able to commit to Islam exclusively. Because the early Muslim converts and leaders were predominantly from the Eko Epe group, and because some Ijebu Epe found full commitment to Islam difficult, many members of the Eko Epe group felt that the leadership of the Muslim community should naturally be reserved for them alone.

13. Gbadamosi, The Growth of Islam, 65 .

14. T.A.O. Avoseh, Short History of Epe (Lagos: Adeolu Press, 1960).

15. Oloruntola, “The Balogun Institution in Epe," 121-2. 
This expectation by the Eko Epe, however, irritated many Ijebu Epe Muslims, both because some of them were strict Muslims, but also because many of them felt that as the original settlers, they should play a significant role in all aspects of town life, including its Muslim community. Yet, as we saw above, it was that very ownership of the settlement that the Eko Epe held against them, because they believed that it was associated with a tendency to continue to participate in non-Islamic practices.

However, it appears that in the 1870s and 1880s relations between the two groups were more cordial. This may have been because of a change in the leadership of both the Eko Epe and the Ijebu Epe. Eko Epe Baale Chief Agbaje enjoyed the cooperation of the Oloja Okuboyejo, described by Oloruntola as "a man of peaceful disposition" because he rebuilt the town's relationship with Ijebu-Ode. ${ }^{16}$ In fact, when the Awujale Fidipote was ousted in 1883, he was allowed to spend the last two years of his life in Epe.

It is possible that a peaceful arrangement might have developed under the leadership by the Baale, who represented the increasingly Muslim town, albeit with some recognition of the traditional institutions linked to the town's Ijebu past. However, it is difficult to say whether such relatively tolerant Islamic leadership would have satisfied the Eko Epe for long, even if it had been acceptable to the Ijebu Epe. In any case, the expansion of British rule intervened.

\section{Islam and conflict between Eko Epe and ljebu Epe post-1892}

When the conflict between the Colony of Lagos and the Ijebu kingdom escalated, the internal tensions within the Muslim community in Epe town led to the re-polarization of Epe politics and the split of the Muslim community into two rival factions along sub-ethnic boundaries.

During the British campaign against Ijebu in 1892, the assistance of the Eko Epe enabled the British troops, consisting of members of the Gold Coast Constabulary and so-called Lagos Hausas, to land. In the following battle at Imagbon, the Ijebu were bitterly defeated. While it is unclear to what degree the Ijebu Epe opposed the support of their Eko townsmen for Lagos at the time of the conflict, the aftermath of the battle greatly disadvantaged them.

The aftermath of the Imagbon war saw the Ijebu kingdom much diminished: while Ijebu Ode came under the jurisdiction of the Protectorate, Epe, like the Remo District and other coastal Ijebu towns, was placed under direct administration from Lagos.

16. Balogun, "Syncretic Beliefs and Practices", 104-5. 
As the Ijebu Epe found it increasingly difficult to turn to Ijebu-Ode for assistance, they became bitter about the Eko-Epe's assistance to the British invaders, which they saw as instrumental to their demise. In order to protect themselves as what they saw as a likely domination by the Eko Epe in the wake of the Imagbon war, a section of the Ijebu Epe again turned to their traditional deities and associations to assert their own importance within the town.

In 1899 the Eko Epe performed a lengthy celebration of a traditional association that required women and those who were not part of it to stay indoors. While the celebration may have been intended simply as an event to bring the (Ijebu) Epe community together at a time of perceived danger, the Eko-Epe Muslims saw it as a threat because it excluded them as Muslims. As the festival was a traditional Ijebu festival, they perceived it as a flagrant trampling on their rights as Muslims, because apart from not being allowed to pursue their livelihoods, they were unable to pray or meet in the mosque. Several of them went out and the ensuring confrontation led to several deaths arson and killing. ${ }^{17}$

Within the Muslim community, each faction of the town was now led by a notable Muslim leader. One faction was led by Mohammad Abu, a respected scholar from the Ijebu Epe side, and another by a prominent and influential Muslim trader and leader from the Eko Epe side, Braimoh Edu who later became the Baale or leader of the Muslim community. The first conflict erupted over different expectations over how the two groups should live together, as local and Islamic expectations of how marriage should be contracted were somewhat different. In 1898 , the community became deeply divided over the payment of bride wealth. Eventually, the Governor visited the town to mediate but was only partly successful ${ }^{18}$. However, a positive side-effect of the encounter was that Epe and Lagos then agreed to the setting up of one of the first Muslim schools in Nigeria in Epe, which opened in the same year.

When the administration from Lagos was extended eastwards beyond Ikorodu District, Epe Provincial Council was formed in 1901. As in other parts of the Colony and Protectorate, the members of the council were appointed by Government.

There may have been many reasons why the Provincial Council included five Muslim leaders of the Eko Epe side, and only one representative of the Ijebu Epe; Chief Ogunbona, a non-Muslim. Lagos may have wanted to reward their allies in the battle against Ijebu-Ode, but it may also have been anxious not to appear anti-Muslim, especially in the face of the then widespread Muslim opposition to Western education.

17. Gbadamosi, The Growth of Islam, 162. 
The dominance of the Eko Epe in the colonial administration was further entrenched by the fact that the Muslim community held a meeting at the residence of one of its influential members, Braimoh Edu, which was seen as another form of discrimination by the Ijebu Epe. ${ }^{18}$ The dominance of the Eko Epe in the Epe Provincial Council offended the Ijebu Epe. Seeing themselves as the original settlers, they did not expect to be relegated to the sidelines, and they suspected their Eko Epe counterparts of attempting to create and nurture a new Muslim dynasty in the town.

These suspicions were confirmed when the Muslim members of the council challenged the Government instructions on the basis that the Council's deliberations should have been guided by the principle of native law and custom. For the Eko Epe members of the council, who were not only more numerous but also more literate than the Ijebu-Epe, this made no sense, and they insisted that the new Provincial Council should be guided by Islamic codes and principles. ${ }^{19}$

The second event was the heightened tension between these groups over the control over the Central Mosque. As elsewhere in the Muslim world, the Central Mosque was built through collective efforts of all member of the community, and it was therefore meant to be open for people for prayer, especially the Friday noon prayer event without any discrimination whatsoever.

However, as relations between Eko Epe and Ijebu Epe declined, the election of Alfa Mota from Ijebu Epe as the new Chief Imam for the Central Mosque further increased ill-will among the Eko Epe. In response to Alfa Mota's emergence as the Chief Imam, the Eko Epe prevented the Ijebu Epe from attending as well as worshipping with them at the Central Mosque again. In January 1903 Government ordered the closure of the Central Mosque to both groups in order to forestall further conflict and a possible breach of the peace in the town. ${ }^{20}$

Eventually both parties found an alternative place of communal worship. As might be expected, this course of events did not by any means bridge the division between the two rival groups. Instead, government decisions led the way to another solution. As the friction between the two groups intensified, the Ijebu Epe demanded their own council. Epe Provincial Council was dissolved in 1904, and both communities within Epe were given their own council in 1905.

While the Council of Epe Eko was entirely Islamic in its composition, the council of the Ijebu Epe reflected the importance of traditional and pre-Islam-

18. Balogun, "Syncretic Beliefs and Practices", 103-4.

19. Ibid., 105.

20. Ibid., 103-4. 
ic institutions. Thus, it included representatives of the Osugbo, the traditional advisory body for the ruler or Oloja, and of the Regberegbe or age grade-associations, which played an important role in the town. ${ }^{21}$ As conflict and tension between the communities continued, the two communities of Epe separated also in terms of their town structures, and while the ruler of Ijebu Epe continues to hold the traditional title of the Oloja of Epe, the ruler of Eko Epe is now known as the Olu of Epe.

\section{Islam, politics, and the making of two communities}

This article has shown that the struggle and competition for the control of spiritual space between Ijebu Epe and Eko Epe was linked to strategies of competition and concerns over subjugation and persecution between the two factions. Despite the fact that the town was increasingly united by Islam, which provided the institutions, the framework and the guidelines for realizing the cohesion and strength of the Muslims, external and internal factors made the smooth functioning of the Muslim community difficult. As people of different ethnic backgrounds held different attitudes about their role in the town, they mobilized their different values and norms, reflecting different cultural heritages and origins.

While the Eko Epe adopted Islam without reservation, their great numbers and the political dominance of their Islamically legitimated institutions encouraged the Ijebu Epe to fall back on their traditional practices. Not all Ijebu Epe Muslims are likely to have welcomed or supported this process, but because the Ijebu Epe mobilized traditional means of affirming and controlling the community, this confirmed prejudices by the Eko Epe about their ability to practice Islam exclusively. It seems that while political disagreement between the two groups did not prevent individual conversion or practice, it colored the way in which each group saw the Islam practiced by themselves and the other faction. The Eko Epe saw themselves as the proper Muslims and the Ijebu Epe as the 'so-called' Muslims, and the Ijebu Epe saw themselves as Muslims and the Eko Epe as those who used their earlier conversion to exclude them.

Because the political conflict between the two Epe communities often centers on the mobilization of Islam versus the traditional Ijebu institutions of the town, the Eko Epe are usually identified with the practice of Islam that is considered untainted by any traditional religion or custom.

21. Ibid., 181. 
However, the struggle over the Central Mosque shows that they also adopted the kind of reasoning that was hitherto associated with the Ijebu Epe. The reason the Ijebu Epe revived the Olojaship and imposed curfews for traditional reasons was that they felt that they should be able to control the town because they were the first settlers. Similarly, it seems that many Eko Epe opposed the ascension of Alfa Mota as the Chief Imam because they felt that they should continue to exercise control over the Muslim community because they were the first converts and by implication that they brought Islam to the town (meaning that they should have produced the Chief Imam). They also claimed to be more knowledgeable, versed in both Quranic and Arabic education than the Ijebu Epe.

The importance of the Central Mosque for the identity of the Eko Epe as a community or town in its own right is also illustrated by the ways it has been used since the early twentieth century. The new Central Mosque plays a very significant role in defining Epe community because it remains the center for the dissemination of information, for guidance and learning, leadership mentoring, and of course, the ways in which religion and tradition interface and interact in the community. Today, it is the tradition and custom in Epe community that the Olu, the traditional leader of Eko Epe, is turbaned in the Central Mosque by the Chief Imam of the community. In other words, there is no demarcation between the Mosque and the political leadership in Eko Epe community.

Of course, most of the town's festivals are Islamic, but the historic KayoKayo festival, which commemorates the figure of King Kosoko, also includes the Central Mosque in the celebration activities. The festival starts with special prayers for peace and political stability at Central mosque and the Oba's palace. This is followed by al-Kansara bath, paying homage to the ancestors of Eko Epe at their respective palaces as a mark of respect, culture and tradition (while on these visits; the Olu would ride in a motorcade around the town). The celebrants then move en masse to the lagoon to wash their feet in remembrance of the emergence of Prophet Nuh (Noah) from his ark after his people had been drowned, while people continue with jubilating, drinking and dining, especially at Popo Oba Square, where King Kosoko kept his ammunition. ${ }^{22}$

Therefore, political power and influence seemed to have become both a magnet and a lodestar for Islam and Muslims in Eko Epe. As the Muslim community expanded in strength, it depended largely for its growth and security on the political influence of the powers that be, who were Muslims. As the Ijebu Epe opposed their political influence by using traditional practices, it

22. Ibid., 103-4. 
became an inherent notion among the Muslim Ummah of Eko Epe to always ensure that they remained in control of the Muslim community to retain their own political power. In other words, the underlying philosophy was to have political influence and power, which they achieved first by conversion and later by emphasizing that only they practiced pure and proper Islam.

\section{Conclusion}

The Yoruba people of the Southwest Nigeria have a sense of themselves as being exceptionally tolerant of religious difference and particularly as having harmonious relations within the society itself. This is viewed as an enduring cultural and ideological trait, and surely derives support from the live-and-letlive ethos of their fore fathers that evolved under changing historical conditions. However, in the case of Epe this proposition hinges on the Yoruba concept of community. If in the early years and decades of Eko Epe and Ijebu Epe relations it seemed possible that one Islamic community could exist, the political contest between the two groups eventually led to a division expressed as cultural and religious difference. This article shows that differences arising from within each religious tradition can work to challenge and disrupt communal amity, though how far this potential is realized depends on many contingent factors.

It remains a fact that ethnic groups are created from within subjective and intersubjective factors and that a mere examination of the objective conditions for their genesis does not provide a full explanation for their existence. Many of us pay lip service to the rather fuzzy ideas of "interplay" between objective and subjective, or historical and structural factors; but it is another matter altogether to demonstrate the actual complexity of ethno-religious phenomena. ${ }^{23}$

Islam upholds that all religious beliefs, with their different aspects and forms, arise from a single, gushing, abundant source, the primordial nature of man, which is neither eternally imposed nor paternally accidental. However, it seems that human beings are not always able to reflect that unity in their own organization. Yet, as the study shows, both elites and religious clerics have used the mosque to settle scores. The mosque thus became an object of political maneuvering in local conflicts over group superiority, but also in strategies followed by individuals to raise their profile. Clearly, conflict can also arise from an elite interest in self-aggrandizement. ${ }^{24}$

23. P. Yeros, Ethnicity and Nationalism in Africa: Constructivist Reflections and Contemporary Politics (New York, NY: Palgrave Press, 2016).

24. O.B. Lawuyi, Moral Imaginings and Nigerian Elite: Playing Satan and God in Performance (Ibadan: University Press, 2014). 
This study also illustrates that there is an important relationship between ethnic polarization, especially when constructed using religious differences as the main impetus. Horowitz argued that "in divided societies, ethnic conflict is at the center of politics, which consequently pose challenges to the cohesion as well as peaceful relations in the state. Thus, ethnic conflict strains the bonds that sustain civility and is often at the root of violence that results in looting, death, homelessness, and the flight of large numbers of people". Because ethnic affiliations can therefore be considered as powerful, passionate and persevering, they can find expression in religious differences. That is why religious diversity plays an important role not only as a social cleavage that derives in social tensions but also in politics. ${ }^{25}$

The article therefore concludes that both academics and policy makers should give more attention to identifying the potentially positive effects of societal norms and their effectiveness deriving from cultural differences. Identifying these effects would be a vital first step towards establishing truly multi(or sub-) cultural society in which the positive aspects of many cultures are accepted, incorporated and the value in diversity is recognized. This study therefore provides empirical evidence that differences between ethnic groups do affect some aspects of the religious practices and that these differences are aptly rooted in their varied cultural differences and heritage.

\section{Bibliography}

Avoseh, T. A.O. Short History of Epe. Lagos: Adeolu Press, 1960.

Balogun, M.A.. 'Syncretic Beliefs and Practices amongst Muslims in Lagos State Nigeria; with special reference to the Yoruba speaking people of Epe', Unpublished PhD Thesis, University of Birmingham, Birmingham (UK), 2011.

Gbadamosi, T.G.O. The Growth of Islam among the Yoruba, 1841-1908. London:

Longman, 1978.

Oloruntola, Philip. “The Balogun Institution in Epe”, in The Balogun in Yoruba Land: The Changing Fortunes of a Military Institution, ed., Oluwasegun Mufutau Jimoh and Philip Oloruntola. Ibadan: Bookbuilders, 2016.

Oyeweso, S. Journey from Epe: Biography of S.L. Edu. Lagos: West African Book Publishers Limited, 1996.

25. D. Horowitz, Ethnic groups in conflict (California: University of California Press, 1985). 